\title{
Factors determining exportation and internationalization in family businesses: The importance of debt
}

\author{
S. Benito-Hernández* \\ Universidad Politécnica de Madrid \\ sonia.benito@upm.es \\ T. Priede-Bergamini \\ Universidad Europea de Madrid \\ tiziana.priede@uem.es \\ C. López-Cózar-Navarro \\ Universidad Politécnica de Madrid \\ cristina.lopezcozar@upm.es
}

\begin{abstract}
This study focuses on the factors that may influence Spanish family owned businesses to decide to export and move towards internationalization, posing their level of debt as a possible determining factor. To do so, a review of publications on the subject has been carried out, as well as an empirical study using a sample of 1,846 businesses, which include both family and non-family firms. The results seem to show that the debt level of businesses whose propriety and management are handled by a family differs from that of those that do not fit this characteristic, especially where the decision whether or not to export products abroad is concerned.
\end{abstract}

Key words: management, family business, internationalization, debt, export.

*To whom all correspondence should be addressed.

\section{Introduction}

The internationalization strategies of large firms have been studied in depth, both theoretically and empirically. However, there are not many studies that focus solely on the particular case of family businesses. Given the importance of these organizations within the fabric of business in major economies, the rise in interest in such studies in recent years does not come as a surprise. According to data from the Spanish Institute for Family Businesses, in Spain there are 2,9 million family businesses. This accounts for $85 \%$ of the total businesses in Spain, which create approximately $70 \%$ of all job positions in the private sector and contribute $70 \%$ of the GDP and exports.

Along the same lines, the European Family Businesses Group reached a consensus in 2008 regarding the definition of a family business, published as such by the European Commission, which was non-existent until then. The definition combines the two ideas around which the concept of a family business has traditionally revolved: sharing property, ownership and management among members of a same family. However, this definition does not include a third notion that is also of considerable importance: the will that the company remain over time and be passed on to future generations (Zhara, 2003; Casillas \& Acedo, 2005; Crick, Bradshaw \& Chaudry, 2006). It may therefore be basically defined as a business in which members of one or various families share, to a great extent, capital, management responsibilities, and the intention of passing the business on to future generations (Gallo, 1995; Astrachan, Klein \& Smyrnios, 2002; López-Cózar \& Priede, 2009).

One of the main characteristics of this type of business is the concurrence of three groups of people: family members, business owners, and business managers, each one with its own system of values and objectives, which brings about multiple, complex relationships. It is precisely these interrelationships that provoke a difference in behaviors compared to other types of businesses. In this sense, various authors highlight that due to the particular interests of a family that owns a business, the process of establishing strategic goals and planning to reach them are not the same as those of their non-family counterparts (Martín \& Cabrera, 2007). Although there are exceptions, growth does not tend to be a primary goal of these types of firms (Claver, Rienda $\&$ Quer, 2009).

In relation to internationalization strategies, family businesses have certain peculiarities that may be considered strengths in such processes. Among these, the most important are experience and knowledge of the business, the product, and the sector itself; as well as having a solid business culture with shared values, convictions and a strong sense of group belonging, and a long-term perspective. In 
this sense, trust, loyalty and commitment are greater than in other businesses, which make them stronger when faced with adversities (Burton \& Schlegelmilch, 1987; Swinth \& Vinton, 1993; Lansberg, 1999; Okoroafo, 1999; Habbershon \& Williams, 2000; Karlsson, 2001; Tsang, 2002; Gallo et al., 2009; Adendorff \& Boshoff, 2011).

Nonetheless, there are other aspects that result in limitations, including problems caused by generational changeovers such as a lack of professionalism or poorly defined organizational structures (Gallo \& Sveen, 1991; Gallo \& García-Pont, 1996; Graves \& Thomas, 2004). In addition, they may encounter problems with financing (Barry, 1975; Gallo \& García-Pont, 1996; Fuentes et al., 2007; Claver et al., 2009).

In general, various studies agree that the international activity of family businesses is lower than that of non-family businesses (Gallo \& García-Pont, 1996; Okoroafo, 1999; Davis \& Harveston, 2000; Graves \& Thomas, 2004; Menendez, 2004; Fernández \& Nieto, 2005, 2006; Sacristan, Rico \& Lafuente, 2011). Gallo and Sveen (1991) suggest that internationalization in family businesses is slower than in non-family ones, and that they generally tend to focus on the needs of domestic markets, except in those cases where managers have international experience of a personal nature (travelling, knowledge of foreign languages, contacts or family in other countries, etc.). Claver et al. (2009), state that family businesses engage in international activity in a similar way to non-family ones (measured both by their propensity to export, as well as the number of direct foreign investments made). Other studies show that in the case of small and medium enterprises, there is not much difference as far as the tendency to internationalize among those that are family and those that are not (Casado et al., 1997).

At the same time, within a family business, great differences may be found among first, second and third generations. Okoroafo (1999) suggests that businesses that have not undergone internationalization in the first or second generation will most likely not do so in the future. Along the same lines, Westhead, Wright and Ucbasaran (2001), consider that it is more probable that the first generation be more inclined to export because they have greater resources and knowledge. However, other works point out just the opposite; some studies reveal that it is easier to initiate the internationalization as of the second generation (Gallo \&García Pont, 1996; Fernández\& Nieto, 2005). Claver et al. (2009) find no evidence to support that there is greater foreign investment from the second generation on. Furthermore, Okoroafo and Perryy (2010) confirm that the second generation is more receptive to embarking on an internationalization process.

Other studies are centered on the capacities, attitudes and personal characteristics of the CEO (Gallo \&García Pont, 1996; Davis \& Harveston, 2000; Graves \& Thomas, 2004; Casillas \& Acedo, 2005), as well as their level of education and age. For example, Davis and Harveston (2000) reach the conclusion that there is a positive relationship between the education of an executive and the degree of internationalization of their company. However, age does not influence their propensity to export.

The aim of this paper is to study which factors influence whether or not a family business in Spain decides to initiate exportation and internationalization. Special attention will be paid to debt levels, since as is apparent in the epigraph following, there are various research lines and results on the matter. To reach the objective stated this work reviews bibliographic references on factors that influence the internationalization strategy of a family business. It also performs an empirical study based on the data obtained in the Business Strategy Questionnaire (carried out by the Ministry of Science and Technology and the SEPI foundation) of 1,846 industrial organizations (both family and non-family), within the Spanish industrial sector. The paper concludes with some final reflections based on the results obtained in the empirical comparison.

\section{Literature review}

In general terms, the literature shows that there seems to be a certain consensus as to the negative relationship between family ownership and internationalization, more so in the case of small-sized businesses (Fernández \& Nieto, 2002; Gallo \& García-Pont, 1996; Okorafo, 1999; Graves \& Thomas, 2008). In such studies, the internationalization of a family business is usually measured by the activity and intensity of exports. However, it must be made clear that a business may decide to export sporadically based on production needs, without necessarily engaging in an intentional internationalization strategy. This paper, therefore, studies both of these aspects. According to the most recent data offered by the Instituto de la Empresa Familiar, in Spain the majority of these businesses carry out less than $25 \%$ of their sales abroad, with only $19 \%$ of them surpassing the $50 \%$ mark. It can therefore be stated, in global terms, that the level of internationalization of Spanish family SMEs is low and fundamentally carried out via low risk strategies such as exporting.

In a recent empirical study published for industrial and service providing companies (Miller, Le Breton-Miller \& Lester, 2010) it is made evident that when explaining the performance of certain businesses, it is necessary to analyze not only their property structure, but to go greater in depth into factors such as who the owners and managers of a business are, and how the social setting in which the business operates influences in its strategic priorities. The authors conclude that family owners and managers, influenced in their decision-making by stakeholders, tend to adopt more conservative strategies than non-family businesses. That is to say, they tend to minimize investment in research and development, capital expenditure and debt, and prefer to adopt more generous dividend policies. In this way they feel they are minimizing risk and the shareholders feel safer. Internationalization strategies would be posed in the same manner, requiring great effort and capital in order to be carried out. Along these same lines of thought, a study conducted by Ling Lin and Fung Wu (2010) for 
organizations in the financial sector demonstrates the negative relationship between family property and assumption of risk. In this sense, the following hypotheses are proposed:

\section{Hypothesis 1: Family ownership influences negatively the} decision to export in the industrial sector.

Hypothesis2: Family ownership influences negatively the decision to internationalize in the industrial sector.

In relation to debt level and capital structure to finance investment and internationalization, there are a great many studies on the subject. The recent theory on financial hierarchy or pecking order (Myers \& Majluf, 1984; Romano, Tanewski \& Smyrnios, 2000; Poutziouris, 2001) postulates that businesses establish a hierarchical order regarding financial decisions. There is a great consensus among authors that these businesses prefer, primarily, selffinancing and reinvesting profits to any other source of financing (Corbetta, 1995; Poutziouris, 2001). However, there is not a clear consensus about their preference regarding going into debt. Some studies show that family businesses prefer going into debt before increasing capital to finance their investments, so as to avoid allowing new nonfamily shareholders (Chaganti \& Damanpour, 1991; Anderson, Mansi \& Reeb, 2003). While other authors show that family businesses prefer not to go into debt and be more prudent, in order to avoid losing their independence to creditors and maintain control in the case of financial crises (Gallo, Tàpies \& Cappuyns, 2004; López-Gracia \& AybarArias, 2000).

In this sense, Aronoff and Astrachan (1996) explain the relationship between growth and financing through debt within family businesses. After analyzing a variety of studies on family businesses in the United States, they conclude that in the majority of cases, these types of businesses prefer not going into debt so as to avoid the risks involved, despite the limitations this decision may have on the growth of the business and consequently on their internationalization strategy. Seemingly, family businesses ascertain that growth, debt and risk increase the complexity of family relations, and therefore prefer to keep the business within more controllable dimensions. The authors suggest that family businesses should find a balance between capital and debt, allowing them to grow and maximize their performance, while at the same time planning and communicating such strategies correctly through government bodies.

Years later, Graves and Thomas (2008) recognize the importance of internationalization to promote the growth of family businesses and analyze the principal factors that determine such processes through an empirical study, in which they reached some interesting conclusions. Family businesses initiate traditional processes of internationalization and the main factors are: the level of commitment of the management team, the availability of financial resources, and the wish to compromise these resources and develop the necessary capacities for internationalization. Given that family businesses have specific preferences as far as privacy and control are concerned, they prefer internal financing policies, favoring the reinvestment of their own funds to capital increase or long-term debt, which determines, traditional pathways for internationalization policies. This hierarchical preference in the choice of financial sources of family businesses coincides with the literature on the subject (Gallo et al., 2004; Poutziouris, 2001).

According to Blanco, De Quevedo and Delgado (2009) the aspiration of perpetuating the family's control over a longterm period of time, a key defining factor, leads these types of businesses towards following this financial policy even more so, coinciding with the cited theory on financial hierarchy or pecking order, family businesses give priority to internal financing and, in the case that this is not enough, turn towards debt, leaving increasing capital as a last option. Seemingly, this result is related to the generational period of the family business, which would not have been taken into consideration by previous studies, therefore the differences in the results referring to debt. In fact, in first generations it is the family unit that governs and makes financial decisions based on sacrifice and savings, resulting in the majority of investments being self-financed with owners' capital and retained earnings. As the business and its managers evolve and generations change, family ties diminish causing a variation in the commitment and capacity for sacrifice, as well. Decisions regarding financing are based on debt, more than on capital increase. This is due to the great aversion towards a loss of family control, and on a second note, because going into debt is cheaper than self-financing.

Family businesses are usually reluctant to increase capital, because this results in allowing access to new shareholders. Therefore, they tend to depend more on self-financing and only turn towards debt, as previously stated, in cases where self-funds are not enough (Rodríguez \& López, 2004). Sonfield and Lussier (2004) carry out a study in which they compare diverse aspects of the family business across generations. One of the main results obtained is a clear preference of the first generation of a family business towards using self-capital with respect to the following generations, demonstrating that the use of debt becomes generalized as time passes, generations change and the business evolves. These same authors (Lussier \& Sonfield, 2009) -in a study that gathers data from six countries regarding the influence of the founder in business strategiesshow evidence that there is a significant positive correlation between the influence of the founder and the use of selfcapital, rather than debt, to finance investments. Finally, in two recent works that study a small sample of medium-sized African businesses, results show a negative relationship between debt levels and profitability (Obert \& Olawale, 2010; Olufunso, Herbst \& Roberts-Lombard, 2010).

Given the information presented, as far as the relationship between debt and the family business is concerned, this study intends to contribute results and conclusions on the topic, and therefore, the following hypothesis is proposed: 
Hypothesis 3: A negative relationship exists between the export decision of a family business and the debt level.

Other variables had been analyzed as influencing factors on the export decision, such as size, age of the company and the number of products. In relation to size, a family business is closely linked to small and medium enterprises, which account for a great part of the business scheme in most countries, generating employment, wealth, growth and serving as an essential source for business capacity and innovation. This takes on particular relevance in Spain, where more than $99 \%$ of businesses are SMEs (INE, 2011). Now, it is necessary to clarify that although many Spanish family businesses will be considered within the category of an SME, they are not all, since there are also large-sized family businesses.

The internationalization phenomenon has been widely analyzed in a great many theoretical and empirical works, where the size of a business (Bonacorsi, 1992), the resources and capabilities (Knudsen \& Madsen, 2002; Álvarez, 2004), and the characteristics of managers are the most marked variables in terms of conditioning factors (López, 2006). In an empirical study carried out in Germany on the situation and future perspectives of family industrial organizations, it is shown that although these types of businesses possess less products and clients due to their high degree of specialization and smaller size, they are able to export their products all over the globe (Kayser \& Wallaw, 2002). As far as size, most empirical studies find a positive relationship between the size of the business and their export activity, which is supported by obvious theoretical arguments, since small businesses generally have fewer resources available for initiating such a process (Manolova et al., 2002); however, other studies argue that company size does not always determine its international activity (Majocchi \& Zucchella, 2003).

On the other hand, although there is not a general consensus in the literature, most authors coincide that second or third generation family businesses, that is to say, those that have been in business for longer periods of time, are more inclined to initiate an internationalization process (Gallo \&García-Pont, 1996; Fernández\& Nieto, 2005; Okoroafo \& Perry, 2010).

Finally, in the same way as other businesses, family ones should also initiate a diversification process in search of reducing global risk, improving their competitive edge in the future, gaining greater stability, and creating value (Haque \& Hassan, 2001, Lester \& Parnell, 2006). Similarly, authors such as Otto and Marjo-Riitta (1994) identify the number of products, among other factors, as an influential variable in decision to export. For this reason, it is foreseen that a positive relationship may exist between diversification and internationalization in family businesses. This study, therefore, includes the variables of size, age and number of products of a firm as control variables.

\section{Data analysis and methodology}

\section{Sample and data collection}

This study has gathered data from the Encuesta sobre Estrategias Empresariales (ESEE) [Survey on Business Strategies]. The ESEE came about in 1990 thanks to an agreement between the Ministry of Science and Technology (at the time, the Ministry of Industry and Energy), and the SEPI Foundation (previously the Fundación Empresa Pública), responsible for its design and control through the Program for Economic Research.

The ESEE is a statistical survey that collects data from an annual business survey sent to a panel of Spanish manufacturing companies regarding various aspects related to their strategic behavior and decision-making. It also includes information about their results and account balances. The sample is representative of the Spanish manufacturing sector. Although this source of information contains data as of 1990, this paper concentrates on the year 2007. One of the common characteristics of the data set is that firms participating in the questionnaire are selected according to a selective sampling method. Table 1 shows the technical data from the study.

\section{Table 1: Technical data from the study}

\begin{tabular}{|c|c|}
\hline \multicolumn{2}{|l|}{ Population } \\
\hline Unit & Spanish manufacturing sector \\
\hline Questionnaire design & SEPI Foundation \\
\hline Population types & More than 100.000 elements. \\
\hline Reach & National \\
\hline Time period & Data from 2007 \\
\hline \multicolumn{2}{|l|}{ Sampling } \\
\hline Type of sampling & $\begin{array}{l}\text { Random stratified census according to } \\
\text { activity sector and firm size. }\end{array}$ \\
\hline Sample size & $\begin{array}{l}\text { 1.846 Spanish manufacturing firms } \\
0,02(\mathrm{p}=\mathrm{q}=0,50)\end{array}$ \\
\hline Sampling error & $95 \%(\mathrm{~K}=2$ sigma $)$ \\
\hline Level of confidence & Soluciones Estadísticas de Productos \\
\hline Data treatment & $\begin{array}{l}y \quad \text { Servicios } \quad \text { (SPSS) [Statistical } \\
\text { Solutions for Products and Services] }\end{array}$ \\
\hline
\end{tabular}

Source: Author-compiled data

\section{Variables and measures}

\section{Dependent variables}

In this work, different comparative models are presented for both family and non-family businesses. These models analyze the internationalization of the Spanish manufacturing sector, using export propensity as a dependent variable. However, as previously mentioned, there are studies that affirm that a business that exports is not necessarily immersed in an internationalization process, since the decision to export may be sporadic. Therefore, in order to understand whether or not this process is really being carried out, the ratio of export sales to total sales must be determined (Fernández \& Nieto, 2005). 
For this reason, two dependent variables are used. On one hand, the firm's export propensity (EXP) is measured, which is to say, whether it exports or not. In this case, the dependent variable is dichotomous and takes the value of 0 if it does not export or 1 if it does.

On the other hand, and in order to explain not only if the firm exports, but also if there is an intentional internationalization process in place, the export intensity has also been measured (INT), through a continuous variable representing the ratio of sales export to total sales or the export intensity.

\section{Independent variables}

Family ownership has been included in the first model as an explanatory variable (FAM). It is defined as a dichotomous variable that takes two values, either 0 or 1 . It takes a value of 1 when the business is family-owned and a value of 0 when it is not. In this way, what is analyzed is whether family ownership of a business favors international activity or vice versa. The intention is, therefore, to analyze if family ownership has a negative relationship to internationalization, as the literature indicates, and whether or not the behavior of these types of firms differs from that of non-family businesses.

The debt level of the firm (DEB), measured by the ratio of outside debt to the total liabilities. This ratio explains how the company can finance their activity with their own resources and what degree of dependency lies with external agents. As mentioned in the literature review, there is evidence that for family business a negative relationship exists between exporting and debt level. This study will analyze whether this variable influences in the export propensity of the business, and therefore on a possible internationalization process. It will also take a look at the differences that may exist between these variables as compared to non-family businesses.

\section{$D E B=($ Debt $\quad /$ liabilities $) * 100$ (Formula 1)}

An interaction variable has also been added to the model: DEB FAM. The objective is to be able to analyze whether the effect of the debt is actually greater in these businesses due to their family nature. This variable is therefore defined as:

$$
\begin{aligned}
& D E B_{F A M}=(\text { External resources /Liabilities }) * \\
& \text { Family ownership } * 100 \quad \text { (Formula 2) }
\end{aligned}
$$

Diversification is another variable that has been included in the models presented (DIV). This is due to the fact that one of the reasons why a company decides to export is in order to try to obtain a reduction in global risk, in the same way as through a strategy of diversification. This has been included as a dichotomous variable that takes value 0 or 1 . It takes a value of 1 when the company diversifies and 0 when it does not. The company does not diversify if it only defines a product with a three-digit CNAE [Spanish economic activity classification system] code and does when it defines more than one product with several different codes, within the same sector (related) or a different sector (not related) (Almodóvar et al., 2009).

\section{Control variables}

The age of a business is a factor that may affect its international projection (ANT). The literature confirms that young businesses have less international projection than older ones. On the other hand, business development in international markets can take time, in which case older businesses tend to penetrate more into these markets (Smith, Strojer \& Dilling-Hansen, 2002). Therefore, a variable indicating the age of the business has been created. This variable takes the value of 0 , 1 or 2 , depending on whether the business has been running more than fifty years, between 20 and 50 years, or less than 20 years respectively.

In addition, the size of the business has been included, measured by the number of workers (SIZ). Size has been one of the most widely analyzed variables in the scientific literature regarding the export behavior of businesses (Bonaccorsi, 1992; Calof, 1994). It is considered that companies of larger size have a greater availability of resources to dedicate to other activities. The general evidence demonstrates that greater size increases the probability that a business will export. It also increases the business's export intensity, although there is less of a consensus on this point (Bonaccorsi, 1992; Wagner, 2001). Therefore, the control variable of business size is included, defined as a continuous variable measured by the number of employees in the firm.

Lastly, the sector in which the business operates may condition, to some extent, its strategy and results (SEC). A dummy variable has therefore been included to identify the sector a business belongs to (López Rodríguez, 2006; Almodóvar et al., 2009). Table 2 describes all the variables, including nomenclatures and measures. 
Table 2: Variables of proposed models

\begin{tabular}{|c|c|c|c|c|c|c|}
\hline $\begin{array}{c}\text { Variable } \\
\text { Type }\end{array}$ & Study variables & $\begin{array}{c}\text { Variable to } \\
\text { analyze }\end{array}$ & Definition & Name & Source & Values \\
\hline \multirow{2}{*}{ Dependent } & $\begin{array}{c}\text { A business's decision } \\
\text { to export }\end{array}$ & Export propensity & $\begin{array}{l}\text { Analyzes whether or not } \\
\text { the company exports }\end{array}$ & EXP & \multirow{9}{*}{$\begin{array}{l}\text { Data from } \\
\text { the Survey } \\
\text { on Business } \\
\text { Strategies }\end{array}$} & $\begin{array}{c}0=\text { Does not } \\
\text { export }\end{array}$ \\
\hline & Internationalization & Export intensity & $\begin{array}{c}\text { Ratio of export sales to } \\
\text { total sale }\end{array}$ & INT & & Continue (\%) \\
\hline \multirow{4}{*}{ Independent } & Financial dependence & Debt ratio & $\begin{array}{l}\text { Ratio of outside debt total } \\
\text { liabilities of the business. }\end{array}$ & DEB. & & Continue (\%) \\
\hline & Family ownership & $\begin{array}{l}\text { Family } \\
\text { management }\end{array}$ & $\begin{array}{l}\text { If the business is family- } \\
\text { owned or not. }\end{array}$ & FAM. & & $\begin{array}{c}0=\text { Not family- } \\
\quad \text { owned } \\
1=\text { Family-owned }\end{array}$ \\
\hline & $\begin{array}{l}\text { Interaction variable: } \\
\text { adjusted debt due to } \\
\text { family ownership }\end{array}$ & $\begin{array}{l}\text { Ratio of } \\
\text { debt*family } \\
\text { ownership }\end{array}$ & $\begin{array}{l}\text { Ratio of outside funding } \\
\text { to total financing of the } \\
\text { business adjusted to } \\
\text { family ownership. }\end{array}$ & DEB_FAM & & Continue (\%) \\
\hline & $\begin{array}{l}\text { Diversification } \\
\text { strategies }\end{array}$ & Diversification & $\begin{array}{c}\text { Offer of products and } \\
\text { services belonging to } \\
\text { various sectors of activity. }\end{array}$ & DIV. & & $\begin{array}{c}0=\text { Does not } \\
\text { diversify } \\
\text { 1= Does diversify }\end{array}$ \\
\hline \multirow[b]{2}{*}{ Control } & Size & $\begin{array}{l}\text { Number of } \\
\text { employees }\end{array}$ & $\begin{array}{l}\text { Number of employees in } \\
\text { the company. }\end{array}$ & SIZ. & & Continue \\
\hline & Age of the business & Years & $\begin{array}{l}\text { Years the business has } \\
\text { been operating within the } \\
\text { market as of its date of } \\
\text { establishment. }\end{array}$ & AGE & & $\begin{array}{c}0=\text { More than } 50 \\
1=\text { Between } 20-50 \\
\text { years. } \\
2=\text { Less than } 20 \\
\text { years }\end{array}$ \\
\hline Dummy & Sector of activity & Sector of activity & $\begin{array}{l}\text { Sector in which the } \\
\text { business operates. }\end{array}$ & SEC. & & $\begin{array}{c}\text { See Tables } 3 \text { and } \\
4 .\end{array}$ \\
\hline
\end{tabular}

Source: Author-compiled data

Table 3: Values and distribution of the sample within the sectors of activity

\begin{tabular}{|c|c|c|c|}
\hline \multicolumn{2}{|r|}{ Value / industry } & \multirow{2}{*}{$\begin{array}{c}\text { Number of firms frequency } \\
32\end{array}$} & \multirow{2}{*}{$\begin{array}{l}\% \\
1,7 \\
\end{array}$} \\
\hline 0 & Other manufacturing industries & & \\
\hline 1 & Meat industry & 60 & 3,2 \\
\hline 2 & Food and tobacco products & 172 & 9,3 \\
\hline 3 & Beverages & 36 & 1,9 \\
\hline 4 & Textile and clothing & 128 & 6,9 \\
\hline 5 & Leather and footwear & 42 & 2,3 \\
\hline 6 & Wood industry & 65 & 3,5 \\
\hline 7 & Paper industry & 62 & 3,4 \\
\hline 8 & Printing and graphic design & 102 & 5,5 \\
\hline 9 & Chemical products & 120 & 6,5 \\
\hline 10 & Rubber and plastic products & 99 & 5,4 \\
\hline 11 & Mineral non-metallic products & 145 & 7,8 \\
\hline 12 & Ferrous and non-ferrous products & 66 & 3,6 \\
\hline 13 & Metallic products & 235 & 12,7 \\
\hline 14 & Agricultural and industrial machinery & 127 & 6,9 \\
\hline 15 & Office machinery. Data... & 23 & 1,2 \\
\hline 16 & Electrical machinery and materials & 107 & 5,8 \\
\hline 17 & Motor vehicles & 92 & 5,0 \\
\hline 18 & Other transportation materials & 36 & 1,9 \\
\hline \multirow[t]{2}{*}{19} & Furniture industry & 97 & 5,2 \\
\hline & Total & 1.846 & 99,8 \\
\hline \multirow[t]{2}{*}{ Lost } & System & 4 & 0,2 \\
\hline & Total & 1.850 & 100,0 \\
\hline
\end{tabular}


Table 4: Grouping of sectors according to data treatment

\begin{tabular}{|c|c|c|c|}
\hline Name & Definition & Digits & $\begin{array}{l}\text { Values } \\
\end{array}$ \\
\hline $\mathrm{ALI}^{1}$ & $\begin{array}{l}\text { Food, beverages } \\
\text { and tobacco }\end{array}$ & $0,1,2$ and 3 & $\begin{array}{c}0=\text { Belongs to } \\
\text { the sector } \\
1=\text { Does not } \\
\text { belong to the } \\
\text { sector }\end{array}$ \\
\hline TEX.OTH & $\begin{array}{l}\text { Textile, footwear, } \\
\text { leather and other } \\
\text { goods }\end{array}$ & $4,5,8$ and 19 & $\begin{array}{l}0=\text { Belongs to } \\
\text { the sector }\end{array}$ \\
\hline QUI.M & $\begin{array}{c}\text { Chemical, } \\
\text { mineral and wood } \\
\text { products. }\end{array}$ & $\begin{array}{c}6, \\
7,9,10,11,12,13 \\
y 18\end{array}$ & $\begin{array}{l}1=\text { Does not } \\
\text { belong to the } \\
\text { sector }\end{array}$ \\
\hline MAQ.TR & $\begin{array}{l}\text { Machinery and } \\
\text { transportation }\end{array}$ & $14,15,16,17$ & $\begin{array}{c}0=\text { Belongs to } \\
\text { the sector }\end{array}$ \\
\hline
\end{tabular}

\section{Methodology}

The following study presents two analyses and results using different econometric techniques. The first analysis studies the intention to export (model 1) and the second, the internationalization of the firm (model 2).A binary logistic regression model has been used, Logit, for model 1. This type of regression is appropriate given the nature of the dependent variable being measured in this case, since it deals with a limited, dichotomous variable. Lineal regression techniques would not be adequate in this case because the adjusted values of a lineal regression are not restricted to values zero and one. However, in model 2 an OLS model has been used since the dependent variable is continuous.

Both models ( 1 and 2), therefore, differ in the dependent variable. Table 5 shows the models and their characteristics.
Table 5: Models under analysis

\begin{tabular}{|c|c|c|c|c|}
\hline Models & $\begin{array}{l}\text { Object of } \\
\text { analysis }\end{array}$ & $\begin{array}{c}\text { Dependent } \\
\text { variable }\end{array}$ & $\begin{array}{c}\text { Sample } \\
\text { size }\end{array}$ & Hypotheses \\
\hline $\begin{array}{c}\text { Model } \\
\text { 1a }\end{array}$ & $\begin{array}{c}\text { Spanish } \\
\text { manufacturing } \\
\text { businesses }\end{array}$ & $\begin{array}{c}\text { Dichotomous: } \\
\text { Export } \\
\text { propensity }\end{array}$ & 1.846 & \multirow{3}{*}{$H_{1} y H_{3}$} \\
\hline $\begin{array}{c}\text { Model } \\
1 \mathrm{~b}\end{array}$ & $\begin{array}{l}\text { Spanish non- } \\
\text { family } \\
\text { manufacturing } \\
\text { businesses }\end{array}$ & $\begin{array}{c}\text { Dichotomous: } \\
\text { Export } \\
\text { propensity }\end{array}$ & 1.136 & \\
\hline $\begin{array}{c}\text { Model } \\
\text { 1c }\end{array}$ & $\begin{array}{c}\text { Spanish } \\
\text { family } \\
\text { manufacturing } \\
\text { businesses }\end{array}$ & $\begin{array}{c}\text { Dichotomous: } \\
\text { Export } \\
\text { propensity }\end{array}$ & 710 & \\
\hline $\begin{array}{c}\text { Model } \\
2\end{array}$ & $\begin{array}{c}\text { Spanish } \\
\text { manufacturing } \\
\text { businesses }\end{array}$ & $\begin{array}{c}\text { Continuous: } \\
\text { Export } \\
\text { intensity }\end{array}$ & 1.846 & $\mathrm{H}_{2}$ \\
\hline
\end{tabular}

\section{Results}

Table 6 gathers the descriptive statistics of the variables from the different samples. It may be observed that three variables stand out: the first is the export intensity of the firm (INT). That is to say, of the total sales of the firm, which ones are from outside markets. The mean of nonfamily businesses surpasses those of family businesses by 4 points.

In second place, as mentioned in the literature review, family businesses in global terms are of smaller size than non-family businesses (SIZ). This explains their lower export propensity.

Lastly, the debt level (DEB) of non-family businesses is slightly lower than that of a family business. Nevertheless, the difference is so irrelevant that a deeper analysis using other techniques is required.

${ }^{1}$ The variable ALI will not be included in the model to avoid correlation with the rest of the business sectors. 
Table 6: Descriptive statistics

\begin{tabular}{|c|c|c|c|c|c|c|}
\hline \multirow[b]{2}{*}{ Model variables } & \multicolumn{2}{|c|}{ Model 1a / 2} & \multicolumn{2}{|c|}{ Model 1b } & \multicolumn{2}{|c|}{ Model 1c } \\
\hline & $\begin{array}{c}\text { Mean } \\
\text { (Max.-Min.) }\end{array}$ & $\begin{array}{l}\text { Standard } \\
\text { Deviation }\end{array}$ & $\begin{array}{c}\text { Mean } \\
\text { (Max.-Min.) }\end{array}$ & $\begin{array}{l}\text { Standard } \\
\text { Deviation }\end{array}$ & $\begin{array}{c}\text { Mean } \\
\text { (Max.-Min.) }\end{array}$ & $\begin{array}{l}\text { Standard } \\
\text { Deviation }\end{array}$ \\
\hline $\begin{array}{c}\text { EXP (only for type a } \\
\text { models) }\end{array}$ & $\begin{array}{r}0,62 \\
(0-1) \\
\end{array}$ & 0,485 & $\begin{array}{r}0,61 \\
(0-1) \\
\end{array}$ & 0,488 & $\begin{array}{r}0,63 \\
(0-1) \\
\end{array}$ & 0,483 \\
\hline $\begin{array}{l}\text { INT (only for type b } \\
\text { models) }\end{array}$ & $\begin{array}{c}19,16 \\
(0-100)\end{array}$ & 26,833 & $\begin{array}{c}\mathbf{2 0 , 7 8} \\
(0-100)\end{array}$ & 28,270 & $\begin{array}{c}\mathbf{1 6 , 5 7} \\
(0-100)\end{array}$ & 24,259 \\
\hline AGE & $\begin{array}{r}1,36 \\
(0-2)\end{array}$ & 0,699 & $\begin{array}{r}1,37 \\
(0-2) \\
\end{array}$ & 0,711 & $\begin{array}{l}1,35 \\
(0-2)\end{array}$ & 0,677 \\
\hline FAM & $\begin{array}{r}0,38 \\
(0-1) \\
\end{array}$ & 0,487 & & & & \\
\hline DEB & $\begin{array}{l}57,5599 \\
(2-99,9) \\
\end{array}$ & 22,77242 & $\begin{array}{l}\mathbf{5 8 , 5 2 8 2} \\
(2-99,9) \\
\end{array}$ & 22,68463 & $\begin{array}{c}\mathbf{5 6 , 0 2 3 2} \\
(2,9-99,5)\end{array}$ & 22,84331 \\
\hline DEB_FAM & $\begin{array}{c}20,95 \\
(0-100)\end{array}$ & 30,499 & & & & \\
\hline DIV & $\begin{array}{r}0,15 \\
(0-1)\end{array}$ & 0,357 & $\begin{array}{r}0,16 \\
(0-1)\end{array}$ & 0,363 & $\begin{array}{r}0,14 \\
(0-1)\end{array}$ & 0,346 \\
\hline SIZ & $\begin{array}{c}243,27 \\
(1-13,290) \\
\end{array}$ & 725,13 & $\begin{array}{c}293 \\
(1-13,290) \\
\end{array}$ & 857,223 & $\begin{array}{c}163,67 \\
(3-7,295) \\
\end{array}$ & 426,588 \\
\hline QUI.M & $\begin{array}{c}0,45 \\
(0-1)\end{array}$ & 0,498 & $\begin{array}{c}0,46 \\
(0-1)\end{array}$ & 0,499 & $\begin{array}{c}0,44 \\
(0-1)\end{array}$ & 0,496 \\
\hline MAQ.TRA & $\begin{array}{r}0,19 \\
(0-1)\end{array}$ & 0,392 & $\begin{array}{r}0,21 \\
(0-1)\end{array}$ & 0,407 & $\begin{array}{r}0,16 \\
(0-1)\end{array}$ & 0,365 \\
\hline TEX.OTH & $\begin{array}{r}0,20 \\
(0-1)\end{array}$ & 0,400 & $\begin{array}{r}0,19 \\
(0-1)\end{array}$ & 0,394 & $\begin{array}{r}0,21 \\
(0-1)\end{array}$ & 0,409 \\
\hline ALI & $\begin{array}{r}0,16 \\
(0-1)\end{array}$ & 0,369 & $\begin{array}{r}0,14 \\
(0-1)\end{array}$ & 0,346 & $\begin{array}{r}0,20 \\
(0-1)\end{array}$ & 0,400 \\
\hline
\end{tabular}

Table 7: Correlation coefficients between independent variables

\begin{tabular}{c|c|c|c|c|c|c|c|c}
\hline & ANT & FAM & DEU & QUI.M & MAQ.TRA & TEX.OTR & DIV & TAM \\
\hline AGE & 1 & & & & & & \\
\hline FAM & $-0,018$ & 1 & & & & & \\
\hline DEB & 0,186 & $-0,049$ & 1 & & & & \\
\hline QUI.M & 0,044 & $-0,028$ & 0,056 & 1 & & & \\
\hline MAQ.TRA & $-0,052$ & $-0,063$ & $-0,036$ & $-0,439$ & 1 & & \\
\hline TEX.OTH & 0,041 & 0,025 & $-0,020$ & $-0,455$ & $-0,241$ & 1 & & \\
\hline DIV & $-0,058$ & $-0,024$ & $-0,016$ & 0,027 & 0,085 & $-0,065$ & 1 & \\
\hline SIZ & $-0,310$ & $-0,101$ & 0,013 & 0,026 & 0,139 & $-0,182$ & 0,089 & 1 \\
\hline
\end{tabular}

Initially, a test for equality of means between family and non-family businesses was run using the dependent variables and the independent variables (Table 8). The results show that the number of exporting businesses and the percentage of sales exported are lower in family businesses, as previously stated, by a significant amount (INT). As expected, non-family businesses show a lower degree of internationalization than non-family businesses. In the same way, there is a significant difference regarding size and debt levels between both types of businesses (SIZ and DEB).

These results show indications regarding the topic this study intends to contrast. Nevertheless, in order to be able to definitively contrast the hypotheses proposed, it is of interest to broaden this analysis with further econometric models.
Table 8: Test of equality of means between family and non-family businesses

\begin{tabular}{l|c}
\hline & Difference in means \\
\hline EXP & 0,023 \\
\hline INT & $\mathbf{4 , 2 1 * * *}$ \\
\hline AGE & 0,13 \\
\hline SIZ & $0,17^{* * *}$ \\
\hline DIV & 0,018 \\
\hline DEB & $\mathbf{2 , 5 0 * *}$ \\
\hline \multicolumn{2}{l}{}
\end{tabular}

Tables 9 and 10 detail the results from the different models. Table 9 analyzes the factors that influence a business's decision whether or not to export (EXP) and table 10 analyzes the export intensity (INT). It is apparent that the control variables: size and age of the business, are significant in both analyses (models 1 and 2), which strongly supports the proposed models. 
Table 9: Binary logistic analysis.Dependent variable EXP.

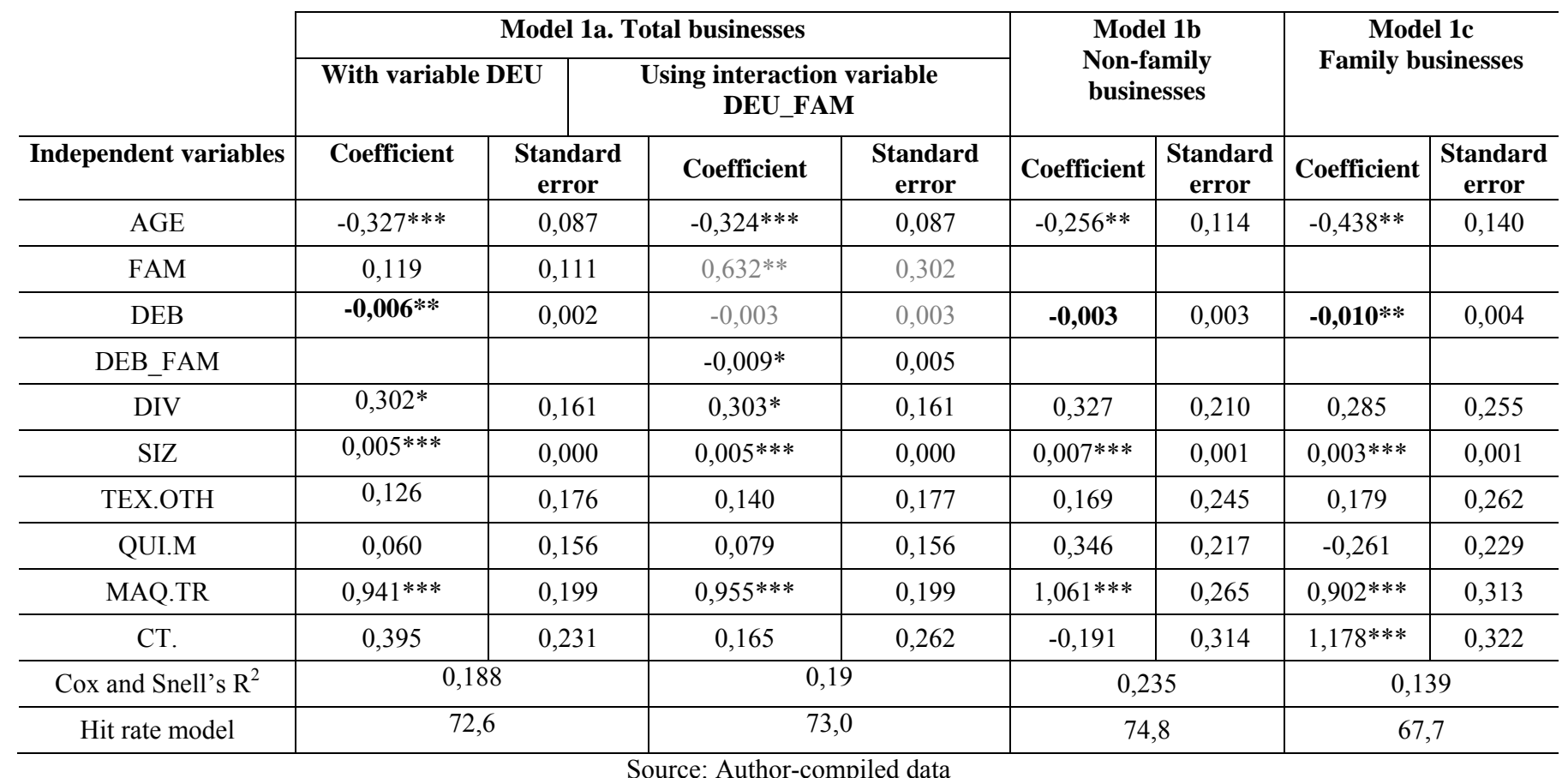

Table 10: OLS Analysis. Model 2.Dependent variable INT.

\begin{tabular}{|c|c|c|}
\hline $\begin{array}{l}\text { Independent } \\
\text { variables }\end{array}$ & Coefficient & Standard error \\
\hline AGE & $-5,253^{* * *}$ & 0,898 \\
\hline FAM & $-2,391 *$ & 1,253 \\
\hline DEB & $-0,030$ & 0,027 \\
\hline DIV & 0,439 & 1,702 \\
\hline SIZ & $0,004 * * *$ & 0,001 \\
\hline TEX.OTH & $-0,185$ & 2,037 \\
\hline QUI.M & $6,579 * * *$ & 1,768 \\
\hline MAQ.TR & $17,727 * * *$ & 2,076 \\
\hline CT. & $21,681 * * *$ & 2,435 \\
\hline $\mathrm{R}^{2}$ & 0,107 & \\
\hline Durbin-Watson & 1,864 & \\
\hline
\end{tabular}

Table 11: ANOVA OLS

\begin{tabular}{c|c|c|c|c}
\hline $\begin{array}{c}\text { Sum of } \\
\text { squares }\end{array}$ & gl & RMS & F & Sig. \\
\hline 134634.51 & 8 & 16829,31 & 26,16 & 0.00 \\
\hline \multicolumn{5}{r}{ Source: Author-compiled data }
\end{tabular}

As far as the variables that concern the study, it is important to emphasize that family ownership of a business (FAM) it is not a significant variable in model 1a $\left(\beta_{\mathrm{FAM}}=0,119\right)$ but it is significant for model 2 . In this line, the results seem to show that family character have no influence in the decision of whether or not to export, but it does and negatively, as shown and expected, in the internationalization decision. Thus, hypothesis 1 cannot be accepted, but we can accept hypothesis $2\left(\beta_{\mathrm{FAM}}=-2,391^{*}\right)$.
Both models seem to show opposing results in this sense, for this reason we have developed goodness of fit techniques $\left(\mathrm{R}^{2}\right.$ and Rate Hit Model for logistic models in table 9, and Watson and ANOVA for GLM in tables $10 \mathrm{y}$ 11 ), with reasonable results. Although is true that $\mathrm{R}^{2}$ are not very high, they are in line with other papers such as López Rodríguez (2006) and Robson and Bennett (2000). The other techniques show suitable results.

The results can explain that the export decision is more conservative and less significant in terms of resources involved, so in this sense family character is not determining. Nevertheless, the internationalization decision is more complex and requires more resources and compromise, so in this case family character is determining and the conservative characteristic of the family firm has an effect on the decision, as it was expected from the literature review (Aronoff \& Astrachan, 1996; Ling Lin \& Fung Wu, 2010).

It may also be observed that in all the proposed models, those businesses that belong to the sector of machinery and transports are greater influenced to export than businesses in other sectors, such as food, beverages and tobacco.

With regards to influential factors in the decision to export or not (Table 9), it is important to highlight that in model 1 , both model types $1 \mathrm{a}$ and 1bexplain greater in depth the export behavior of non-family businesses than that of businesses with family ownership; see the respective $\mathrm{R}^{2}$, which is greater in the sample of non-family businesses than in family ones $\left(\mathrm{R}_{1 \mathrm{a}}^{2}=0,19, \mathrm{R}^{2}{ }_{1 \mathrm{~b}}=0,23\right.$ and $\mathrm{R}_{1 \mathrm{c}}{ }=$ $0,13)$. 
In this regard, it may be observed that diversification is an explanatory factor $\left(\beta_{\mathrm{DIV}}=0,302 *\right)$, but only in the general model. This may be due to the fact that diversification demands a series of changes that require the firm to break the status quo. A family business is not always willing to implement policies that imply a rupture in tradition. Their characteristic aversion towards changes that imply risk, previously proven, may translate into not considering diversification a strategy that minimizes global risk, but rather just the opposite.

Nevertheless, the most interesting results, from the point of view of the third hypothesis formulated, are obtained in model 1a. This model has been estimated using the variable DEU, and later with the interaction variable. The first estimation shows signs that this variable is influential when it comes time for a business to decide whether or not to export and expand their business abroad $\left(\beta_{\mathrm{DEB}}=\right.$ $\left.0,006^{* *}\right)$ However, it cannot be deduced that this is due to its characteristic of family ownership. In the second estimation of the model, an interaction variable has been introduced: DEB_FAM, which appears as significant $\left(\beta_{\mathrm{FAM} * \mathrm{DEB}}=-0,009^{*}\right)$. Thanks to this interaction variable the deduction can be made that the effect of debt is greater on family businesses than on their non-family counterparts when concerning exporting. In addition, in both cases they keep a negative sign as expected.

These results must also take into account results obtained from models $1 \mathrm{~b}$ and $1 \mathrm{c}$, as they support them $\left(\beta_{\mathrm{DEB}} 1 \mathrm{~b}=-\right.$ $\left.0,003, \beta_{\text {DEB } 1 c}=-0,010^{* *}\right)$. This analysis shows that debt levels are significant in family businesses, contrary to nonfamily businesses, when making the decision of whether or not to export, in a negative way. This may be due to the fact that non-family businesses do not condition exporting to going into debt, however, family businesses do. As mentioned in the literature review, this type of firm prefers using their own resources rather than going into debt to finance their investments and expansion. On the other hand, it is apparent that the relationship between exportation variables and going into debt is negative. In this sense, hypothesis 3 may be accepted.

Finally, the results from the analysis of the variable INT (Tables 10-11), which better explains the idea of a firm's internationalization for the reasons previously exposed, are not so enlightening. While increasing debt levels may be influential in the export propensity, they are not so in the export intensity $\left(\beta_{\mathrm{DEB}}=-0,030\right)$. Nevertheless, it can be noticed that although not significant still keeps a negative sign as it happened in previous the models. There are also other important factors, as indicated by the significance of the constant, which better explain the internationalization of a family business. Some probable examples are: strategy, competitive advantages, strategic alliances, which are not analyzed in this study.

\section{Conclusions}

\section{Theoretical contributions and managerial implications}

The results obtained seem to conclude that certain factors, whose influence has been contrasted in the literature on businesses from a general point of view, lose strength when explaining the decision of whether or not to export and internationalize in the case of businesses with family ownership. These results may have certain relevant implications on business practices and on the implementation of policies that boost exporting and future internationalization of family businesses smaller in size than non-family businesses, and in most cases, pertaining to the category of small enterprises. It seems that family ownership does influence negatively in the internationalization process. It has also been proven that these types of businesses generally have a lower degree of internationalization than non-family ones.

The difficulties associated with decision-making regarding a business's move towards internationalization can be greater if the business does not have internal funds readily available to afford the process. In this case, the solution becomes finding external funding, in the way of debt or capital increase. The literature demonstrates that family businesses do not tend to rely on capital increase if it supposes allowing non-family members into the shareholdings and consequently, a loss of control of the family ownership of the firm. Therefore, another possible option is rising outside debt. However, the results of the model show that family businesses try to avoid going into debt as much as possible, occasionally opting for not internationalizing or doing so to a lesser degree if it means increases their financial dependency, due to the allowance of creditors into their liabilities. This fact produces a negative effect on the exporting activity because, as shown in the results, both variables (debt level and export propensity) are significantly related with a negative sign.

One of the most significant conclusions in the research concerns the debt ratio, the capital structure of the family business and the export propensity of the business. In this sense, the debt level of the firm is an influential factor in deciding whether or not to export, but not as much so as the intention of the firm to internationalize. Internationalization is greatly associated with a high degree of uncertainty for a relatively small business based in a domestic market, or even a local one, with a conservative management team aversive towards risk, in which traditional cultures and values are ingrained. For this reason, the motivation towards initiating this process goes beyond the debt capacity of the business, with other factors that are not analyzed in this study taking on importance, such as competitive advantages, strategic alliances, etc.

In the same way, when dealing with the various factors that have traditionally explained exportation and 
internationalization processes in businesses, such as diversification, which has always played a positive role in promoting exporting in general, they do not correspond to the results obtained from family businesses. In familyowned firms, this factor appears as not significant. Other factors that have also been studied and researched throughout the history of entrepreneurship, such as size, age and certain sectors of business, do widely contrast the positive relationship they maintain with their export activity and internationalization, in one type of business as well as the others.

In conclusion, some factors that explain the internationalization of a business in general do not coincide with those that influence in a family business's decision making (see the case of diversification). While other traditionally studied factors, such as size, activity sector or age, are apparent. Nonetheless, one of the main obstacles that makes a family business export to a lesser degree than a non-family firm is the need for financing that requires investments in order to carry out such a process. Within this point, the growth objective of the family business through internationalization is confronted with the family's interests and demands; all the more so when this decision implies risking their wealth and livelihood. They, therefore, tend to be more conservative and careful investors when making these types of decisions.

Finally, it is necessary to point out that this conflict of interests harms the value and future development of the family business, since due to the highly complex and changing outside environment today, it is a requirement to reach the parameters of competitiveness and strategic renewal imposed in such settings to ensure survival and continuity. Hence, the results show that although the level of debt of the family business affect the decision of whether or not to export, nevertheless, higher or lower levels of debt do not affect the export propensity of these firms.

\section{Limitations and recommendations for future research}

However, it is necessary to highlight that this study has clear limitations and areas for improvement, which are at the same time opportunities for further research. With regard to this, there are three main limitations in this paper of which the first is the national character of the sample. The second is the temporary horizon limited to one year of study (a cross sectional research). Thirdly, being a study of a particular sector: the industrial sector. In this sense, it is important to note that, a priori, the influence of the sector is less important, since many needs are common to all sectors.

With regard to future research, it would be interesting to carry out the study with a sample of medium-sized companies (50 to 250 employees), comparing family and non-family firms, and analyzing how the generational period variable affects the company's export decision (highlighting generational problems and nepotism. It would also be interesting to include new variables in the analysis, such as the issues of shared capital as a source of financing. Finally, it would be interesting to repeat this analysis with data from other countries and with larger business enterprise frameworks.

\section{References}

Adendorff, C. \& Boshoff, C. 2011. 'The impact of culturerelated factors on good governance in Greek family businesses in South Africa', South African Journal of Business Management, 42(2): 1-14.

Almodóvar, P., Navas, J. E. \& Huerta, P. 2009. 'La tipología estratégica como factor determinante de la empresa conjunta internacional', Investigaciones Económicas, 33(3): 407-438.

Álvarez, R. E. 2004. 'Sources of export success in smalland medium-sized enterprises: The impact of public programs', International Business Review, 13(3): 383-402.

Anderson, R., Mansi, S. \& Reeb, D. 2003. 'Founding family ownership and the agency cost of debt', Journal of Financial Economics, 68(2): 263-285.

Aronoff, C. \& Astrachan, J. 1996.'Reducing the risks of family-business growth', Nation's Business, 84(3): 52-53

Astrachan J., Klein, S. \& Smyrnios, K. 2002. 'The F-PEC scale of family influence: A proposal for solving the family business definition problem', Family Business Review, 15(1): 45-58.

Barry, B. 1975.'The development of organization structure in the family firm', Journal of General Management, 3(1): 42-60.

Blanco, V., De Quevedo, E. \& Delgado, J. 2009. 'La estructura financiera de la empresa familiar y el cambio generacional', Revista Española de financiación $y$ contabilidad, 38(141): 57-73.

Bonacorsi, A. 1992.'On the relationship between firm size and export intensity', Journal of International Business Studies, 23(4): 605-35.

Burton, F.N. \& Schlegelmilch, B.B. 1987. 'Profile analysis of non-exporters versus exporters grouped by export involvement', Management International Review, 27(1): $38-49$.

Calof, J. 1994. 'The relationship between firm size and export behavior revisited, 'Journal of International Business Studies, 25(2): 367-387.

Casado, F., Merino, F., Salas Fumás, V. \& Solé, J. 1997. 'Eficiencia de las empresas familiares industriales en España', Barcelona Management Review, 4: 42-52. 
Casillas, J.C. \& Acedo, F.J. 2005. 'Internationalisation of Spanish family SMEs: An analysis of family Involvement', International Journal of Globalisation and Small Business, 1(2): 134-151.

Chaganti, R. \& Damanpour, F. 1991. Institutional ownership, capital structure and firm performance. Strategic Management Journal, 12(7): 479-491.

Claver, E., Rienda, L. \& Quer, D. 2006. 'El comportamiento de las empresas familiares y no familiares en los mercados extranjeros: Un estudio comparativo', Cuadernos de Gestión, 6(2): 11-25.

Claver, E., Rienda, L. \& Quer, D. 2009. 'Family firms' international commitment: The influence of family-related factors', Family Business Review, 22(2): 125-135.

Corbetta, G. 1995.'Patterns of development of family businesses in Italy’, Family Business Review, 8(4): 255-265.

Crick, D., Bradshaw, R. \& Chaudry, S. 2006. “ "Successful" internationalising UK family and non-familyowned firms: A comparative study,'Journal of Small Business and Enterprise Development,13(4): 498-512.

Davis, P. \& Harveston, P. 2000. 'Internationalization and organizational growth: The impact of Internet usage and technology involvement among entrepreneur-led family businesses,'Family Business Review,13(2): 107-120.

Fernández, Z. \& Nieto, M.J. 2005. 'Internationalization strategy of small and medium-sized family businesses: Some influential factors', Family Business Review,18(1): 77-89.

Fernández, Z. \& Nieto, M.J. 2006. 'Impact of ownership on the international involvement of SMEs,' Journal of International Business Studies, 37: 340-351.

Fuentes, G., Vallejo, M. \& Fernández, R. 2007. 'Factores a tener en cuenta en la expansión de la empresa familiar', Investigaciones Europeas de Dirección y Economía de la Empresa, 13(2): 75-96.

Gallo, M. 1995. 'The role of family business and its distinctive characteristic behavior in industrial activity,'Family Business Review,8(2):83-97.

Gallo, M., Tàpies, J. \& Cappuyns, K. 2004. 'Comparison of family and nonfamily business: Financial logic and personal preferences', Family Business Review,17(4): 303-318.

Gallo, M.A. \&García-Pont, C. 1996.'Important factors in family business internationalization,'Family Business Review,9(1): 45-59.

Gallo, M.A. \&Sveen, J. 1991. 'Internationalizing the family business: Facilitating and restraining factors,'Family Business Review, 4(2): 181-190.
Gallo, M.A., Klein, S., Tomaselli, S. Montermerlo, D. \& Cappuyns, K. 2009. La empresa familiar multigeneracional. Navarra: EUNSA.

Graves, C. \& Thomas, J. 2004. 'Internationalisation of the family business: A longitudinal perspective', International Journal of Globalisation and Small Business, 1(1): 7-27. Graves, C. \& Thomas, J. 2008.'Determinants of the internationalization pathways of family firms: An examination on family business,' Family Business Review, 21(2): 151-167.

Habbershon, T.G. \& Williams, M.L. 2000.'A model for understanding the competitiveness of family-controlled companies'. In Poutziouris, P. (ed) Tradition or entrepreneurship in the new economy. Manchester: Manchester Business School. P.p.94-115.

Haque, M. \& Hassan, M.K. 2001. 'Diversification as a corporate strategy for a family-controlled business group in a frontier market,' The Journal of Social, Political, and Economic Studies, 26(4): 719-758.

Karlsson, A. 2001. 'En famille: Invisible managers in owner families'. Academic Research Forum Proceedings. FBN 12 $2^{\text {th }}$ Annual World Conference, Rome. Milan: Bocconi University School of Management,

Kayser, G. \& Wallaw, F. 2002. 'Industrial family business in Germany. Situation and future', Famliy Business Review, 15(2): 111-115.

Knudsen, T. \& Madsen, T.K. 2002.'Export strategy: A dynamic capabilities perspective,' Scandinavian Journal of Management, 18(4): 475-502.

Lansberg, I. 1999. Succeeding generations: Realizing the dream of families in business. Boston, Ma: Harvard Business School Press.

Lester, D. \& Parnell, J. 2006.'The complete life cycle of a family business,' Journal of Applied Management and Entrepreneurship, 11(3): 475-487.

López, J. 2006. 'La internacionalización de la empresa manufacturera española: Efectos del capital humano genérico y específico', Cuadernos de Gestión, 6(1): 11-24.

López-Cózar, C. \& Priede, T. 2009. Empresa familiar claves para su supervivencia en un mundo cambiante. La Coruña: Netbiblo.

López-Gracia, J. \& Aybar-Arias, C. 2000. 'An empirical approach to the financial behaviour of small and medium sized companies', Small Business Economics, 14(1): 55-63.

López Rodriguez, J. 2006. 'The internationalization of the Spanish Manufacturing Firm: Effect of the specific and generic human capital', Cuadernos de Gestión, 6(1): 11-24. 
Lussier, R. \& Sonfield, M. 2009. 'Founder influences in family businesses: analyzing combined data from six diverse countries', Journal of Small Business Strategy, 20(1): 103-118.

Majocchi, A. \& Zucchella, A. 2003. 'Internationalization and Performance: Findings from a Set of Italian SMEs. International Small Business Journal, 21(3): 249-268.

Manolova, T., Brush, C., Edelman, L. \& Greene, P. 2002. 'Internationalization of small firms: Personal factors revisited,'International Small Business Journal, 20(1): 931 .

Martín, J. \& Cabrera, K. 2007. 'La gestión del marketing estratégico en la pequeña empresa familiar, 'Cuadernos de Gestión, 7(1): 85-100.

Menéndez, S. 2005. 'Growth and internationalisation of family businesses,' International Journal of Globalisation and Small Business, 1(2): 122-133.

Miller, D., Le Breton-Miller, I. \& Lester, R. 2010.'Family and lone founder ownership and strategic behaviour: Social context, identity, and institutional logics,' Journal of Management Studies, 48(1): 1-25.

Myers, S. \& Majluf, S. 1984. 'Corporate financing and investment decisions when firms have information that investors do not have,'Journal of Financial Economy, 13(1): 187-221.

Obert, M. \& Olawale, F. 2010.'Does debt really matter on the profitability of small firms? A perspective on small manufacturing firms in Bulawayo, Zimbabwe',African Journal of Business Management, 4(9): 1709-1716.

Olufuns, O.F., Herbst, G. \& Roberts-Lombard, M. 2010. 'An investigation into the impact of the usage of debt on the profitability of small and medium enterprises in the Buffalo city municipality, South Africa,'African Journal of Business Management, 4(4): 373-381.

Okoroafo, S.C. 1999. 'Internationalization of family businesses: Evidence from Northwest Ohio, USA,'Famliy Business Review, 12: 147-158.

Okoroafo, S.C. \& Perryy, M. 2010.'Generational perspectives of the export behavior of family businesses', International Journal of Economics and Finance, 2(3): 1524.

Otto, A. \& Marjo-Riitta, R. 1994. 'Prediction of export intentions - managing with structural characteristics?' Scandinavian Journal of Management, 10(1): 17-27.

Poutziouris, P. 2001. 'The views of family companies on venture capital: Empirical evidence from the UK small to medium-size enterprising economy', Family Business Review, 14(3): 277-291.
Quintana, J. 2007. 'La internacionalización de la empresa familiar española’, ICE, 839: 113-120.

Robson, P. \& Bennett, R. 2000. 'SME growth: The relationship with business advice and external collaboration', Small Business Economics, 15(3): 193-208.

Rodríguez, R. \& López, M. 2004. 'La empresa familiar exportadora. El caso de las empresas de congelados y conservas de pescados, moluscos y crustáceos', Revista Galega de Economía, 13(1): 1-19.

Romano, C., Tanewski, G. \& Smyrnios, K. 2000. 'Capital structure decision making: A model for family business,' Journal of Business Venturing, 16(3): 285-310.

Sacristan, M., Rico, G. \& Lafuente, C. 2011.'Spanish SMEs and family firm export behavior: Are there differences in their incremental approach?'Revista de Empresa Familiar, 1(1): 7-21.

Setia-Atmaja, L. 2010. 'Dividend and debt policies of family controlled firms: The impact of board independence,'International Journal of Managerial Finance,6(2): 128-142.

Ling Lin, S. \& Fung Wu, M. 2010. 'Family ownership and risk-taking: Exploring nonlinear effects in financial industry,'African Journal of Business Management, 4(17): 3738-3751.

Smith, V., Strojer, E. \& Dilling-Hansen, M. 2002.'Export performance and investment in R\&D.'Aarhus: University of Aarhus, Danish Institute for Studies in Research and Research Policy. Working paper 2002/4.

Sonfield, M. \& Lussier, R. 2004. 'First-, second-, and third-generation family firms: A comparison,'Family Business Review, 17(3): 189.

Swinth, R. \& Vinton, K. 1993. 'Do family-owned business have a strategic advantage in international joint ventures?'Family Business Review, 4(2): 19-30.

Tsang, E.W.K. 2002.'Learning from overseas venturing experience: The case of Chinese family businesses', Journal of Business Venturing, 17(1): 21-40.

Wagner, J. 2001. 'A note on the firm size-export relationship,'Small Business Economics, 17: 229-237.

Westhead, P., Wright, M. \& Ucbasaran, D. 2001. 'Internationalization of new and small firms: A resourcebased view', Journal of Business Venturing, 16: 333-358.

Zahra, S.A. 2003. 'International expansion of U.S. manufacturing family businesses: The effect of ownership and involvement', Journal of Business Venturing, 18(4): 495-512. 